Vol. 4: 377-384.

\title{
Selenium concentration of Finnish foods: Effects of reducing the amount of selenate in fertilizers
}

\author{
Ekholm Päivi, Ylinen Maija, Koivistoinen Pekka and Varo Pertti \\ Department of Applied Chemistry and Microbiology, P.O. Box 27, Viikki D, FIN-00014 University of Helsinki,
}

Finland

\begin{abstract}
The original two supplementation levels of selenium in multinutrient fertilizers (Se 16 and $6 \mathrm{mg} \mathrm{kg-'}$ fertilizer as sodium selenate; started in 1985) were reduced to one ( $6 \mathrm{mg} \mathrm{kg}^{-1}$ fertilizer $)$ in 1991. The $16 \mathrm{mg}$ supplementation level was intended for use in cereal production. Due to the lowering of the level of Se application, the Se content of spring cereals (spring wheat, oats and barley) has decreased more than that of any other food in the monitoring programme. The present level, $0.1 \mathrm{mg} \mathrm{kg}^{-1}$ for cereal grains, is about $40 \%$ of the concentrations common in 1990 .

The Se concentrations have decreased less in other foods than in cereals. The present Se concentrations in milk products, meat and liver are about 70,60 and $50 \%$, respectively, of the concentrations in 1990.

The average daily human Se intake was $0.08 \mathrm{mg} \mathrm{day}^{-1}$ at an energy level of $10 \mathrm{MJ}$ in 1994 . Animal protein is the main source of Se. About $40 \%$ of the intake comes from meat, $24 \%$ from dairy products and eggs, and $11 \%$ from fish.
\end{abstract}

Key words: cereals, meat, milk, cheese, eggs, intake

\section{Introduction}

The general use of selenium(Se)-supplemented fertilizers began in Finland during the 1985 growing season. From then until 1990 two levels of Se supplementation were used in fertilizers: $6 \mathrm{mg}$ of Se as sodium selenate per $\mathrm{kg}$ in fertilizers used mainly in fodder and hay production, and $16 \mathrm{mg} \mathrm{kg}^{-1}$ in those used in cereal production. A group of experts authorized by the Ministry of Agriculture and Forestry evaluated the effects of this measure from 1984 onwards.
The results were published as Working Group reports of the Ministry of Agriculture and Forestry, as articles in international scientific journals and as papers at conferences (Ekholm et al. 1990, 1991a, Eurola et al. 1989, 1990, 1991, Varo et al. 1988).

Thereafter the fertilization practice was simplified and standardized by lowering the Se level from $16 \mathrm{mg} \mathrm{kg}^{-1}$ to $6 \mathrm{mg} \mathrm{kg}^{-1}$ in all fertilizers (Ministry of Agriculture and Forestry 1990). The new, one-Se-level practice has been in use since the 1991 growing season. Although the range of Se concentrations in foodstuffs had re- 
Ekholm, P. et al.: Selenium concentration of Finnish foods

mained narrow and safe throughout the supplementation period, some Se peak concentrations exceeding $1 \mathrm{mg} \mathrm{kg}^{-1}$ dry matter had been detected in fodder and hay samples from a few single farms. The high values were most probably caused by liberal use of high-Se fertilizers $\left(16 \mathrm{mg} \mathrm{kg}^{-1}\right)$ in the production of grassy feeds and hay. Elimination of these unnecessarily high concentrations was the main reason for lowering the Se level of fertilizers. Human intake of Se was already $0.11 \mathrm{mg} \mathrm{day}^{-1}$ in 1987 and was still increasing slightly in the early 1990 s. Nonetheless, intake remained consistently very good and acceptable, and concern at the possibility of excessive intake was never expressed by either nutrition or medical experts. On the other hand, a certain amount of public speculation had been aroused by the doubts of some environmentalists concerning the possible but unverified effects of leached Se on soil, for example, on the algal bloom in Finnish lake waters.

This article reports the effects of lowering the Se level in fertilizers on the Se concentrations in basic foods and on average Se intake in Finland.

\section{Material and methods}

\section{Sampling}

The sampling system of foods has remained principally unchanged throughout the monitoring period (Varo et al. 1988). Eleven basic foodstuffs were sampled regularly every three months. Purchases were made from eight food stores in the Helsinki area. The meat samples were purchased from 16 stores, and the porcine liver samples from a wholesale dealer. The stores were selected as being representative of Finland's major wholesale food chains. These subsamples give a good overview of the situation countrywide. Sample preparation has been described earlier (Varo et al. 1988).

Samples of whole grain wheat and rye were obtained from commercial mills around the country. Each sample $(2-5 \mathrm{~kg})$ represented 0.1-5 million $\mathrm{kg}$ of grain. The barley and oats samples were chosen from farm samples of the State Grain Storage Center. Each sample represented the harvest of a single farm, and all the Rural Advisory Centres in Finland were covered.

Breast milk samples were obtained from Helsinki University Central Hospital. Each sample was a pool of milks from several donors (median 20).

\section{Analytical method}

Se was analysed by an electrothermal atomic absorption method for food samples (Kumpulainen et al. 1983). The freeze-dried samples were kept overnight at $70^{\circ} \mathrm{C}$, and digested in a mixture of concentrated $\mathrm{HNO}_{3}, \mathrm{HClO}_{4}$ and $\mathrm{H}_{2} \mathrm{SO}_{4}$. Selenium was reduced to Se IV by $4 \mathrm{M}$ $\mathrm{HCl}$, chelated with ammonium pyrrolidine dithiocarbamate and then extracted into isobutyl methyl ketone for atomic absorption determination. The accuracy of the method was tested by determining three certified reference materials regularly during the analysis period (Table 1). Three unofficial control materials were analysed continuously as blinds to test the precision of the analytical method.

Statistical analyses were performed using SURVO, an integrated environment for Statistical Computing and Related Areas-software. The equality of the means was tested by applying the Kruskal-Wallis test, the non-parametric analysis of variance.

\section{Results and discussion}

The effect of redusing the amount of Se in fertilizers is seen clearly in the Se concentrations of grains and basic foods (Tables 2 and 3, Figs. 1-4). 1984 represents the original, unsupplemented Se level common in the early 1980s. In 1990 
Vol. 4: 377-384.

Table 1. Precision and accuracy of the analytical method for selenium.

\begin{tabular}{cccc}
\hline Sample & $\begin{array}{c}\text { No. of } \\
\text { determina- } \\
\text { tions }\end{array}$ & $\begin{array}{c}\text { Mean } \pm \mathrm{SD} \\
\mathrm{mgkg}^{-1} \mathrm{DM}\end{array}$ & $\begin{array}{c}\text { Ref. value } \\
\mathrm{mgkg}^{-1} \mathrm{DM}\end{array}$ \\
\hline
\end{tabular}

Standard reference materials

NIST 1577 a

Bovine liver $\quad 14 \quad 0.670 \pm 0.0260 .71 \pm 0.07$

NIST 1549

Milk powder $\quad 4 \quad 0.110 \pm 0.0050 .110 \pm 0.010$

$\begin{array}{llll}\text { BCR } & 4 & 0.124 \pm 0.007 & 0.132 \pm 0.010\end{array}$

Wholemeal flour

Non-certified control materials

$\begin{array}{lll}\text { Rye flour II } & 230 & 0.027 \pm 0.002\end{array}$

Wheat flour III $\quad 208 \quad 0.246 \pm 0.009$

Milk powder II $\quad 102 \quad 0.075 \pm 0.004$

Milk powder III $72 \quad 0.301 \pm 0.014$

Bovine liver II $\quad 84 \quad 0.568 \pm 0.021$

Bovine liver III $\quad 122 \quad 0.755 \pm 0.030$

NIST $=$ National Insitute of Standards \& Techology

$\mathrm{BCR}=$ Community Bureau of Reference

the Se concentrations of Finnish agricultural products were reaching their plateaus due to the effect of two-level supplementation started in 1985. The impact of the change to one-level supplementation began to emerge in late 1991, which was a transitional year (means not shown in Table 3). The new fertilization practice was affecting all foodstuffs in full by early 1992 (Tables 2 and 3, Figs. 1-4).
Se concentrations have declined in all Finnish agricultural products since 1991. Milk has been the most sensitive indicator food throughout the monitoring period. The Se concentration of milk is known to be closely dependent on that of feeds (Jacobsen et al. 1965, Conrad and Moxon 1979, Aspila 1991). Thus the present change in the Se concentrations of foods was first observed in milk, in summer 1991 (Fig. 2).

About six months later, in December 1991, Se concentrations had started to decrease in all retail foods monitored in the programme (Figs. 1-4). In 1992-1994, the downward trend continued, but more gradually the difference between the annual means being statistically significant $(\mathrm{P}<0.01)$ only for wheat bread and eggs in 1992 and 1993, and for wheat bread and pork fillet in 1993 and 1994 (Table 3).

The Se concentrations of spring cereals (spring wheat, barley and oats) have decreased by more than $60 \%$ since 1990 (Table 2). The present level is about $0.1 \mathrm{mg} \mathrm{kg}^{-1}$ dry matter, which was in fact the original target of cereal grain Se fertilization. Of all foodstuffs, the effect of reducing the amount of Se in fertilizers has been greatest in spring cereals. Mixing imported and domestic grains in milling increases the Se concentrations of flours. Consequently, the Se concentrations of flour products differ from those of domestic grains (Tables 2 and 3).

Farm-to-farm variations in the Se concentration of barley and oats have diminished along

Table 2. Selenium concentration of cereals grown in Finland (mgkg-1 dry matter) in 1984 and $1990-1993$.

\begin{tabular}{|c|c|c|c|c|c|c|c|c|c|c|c|c|}
\hline Sample & No. & $\begin{array}{l}1984 \\
\text { Mean } \pm \text { SD }\end{array}$ & No. & $\begin{array}{l}1990 \\
\text { Mean } \pm \text { SD }\end{array}$ & No. & $\begin{array}{l}1991 \\
\text { Mean } \pm \text { SD }\end{array}$ & No. & $\begin{array}{l}1992 \\
\text { Mean } \pm \text { SD }\end{array}$ & No. & $\begin{array}{l}1993 \\
\text { Mean } \pm \text { SD }\end{array}$ & & $\begin{array}{l}1994 \\
\text { Mean } \pm \text { SD }\end{array}$ \\
\hline Spring wheat & 12 & $0.01 \pm 0.01$ & 24 & $0.28 \pm 0.08$ & 18 & $0.12 \pm 0.06$ & 14 & $0.12 \pm 0.02$ & 21 & $0.11 \pm 0.03$ & 6 & $0.11 \pm 0.02$ \\
\hline Winter wheat & & $0.01^{*}$ & 22 & $0.07 \pm 0.04$ & 13 & $0.04 \pm 0.05$ & 9 & $0.04 \pm 0.02$ & 15 & $0.04 \pm 0.04$ & 5 & $0.02 \pm 0.01$ \\
\hline Rye & 10 & $0.01 \pm 0.01$ & 23 & $0.07 \pm 0.03$ & 15 & $0.06 \pm 0.03$ & 8 & $0.03 \pm 0.01$ & 18 & $0.03 \pm 0.02$ & 4 & $0.03 \pm 0.02$ \\
\hline Barley & 50 & $0.01^{* *}$ & 100 & $0.23 \pm 0.15$ & 100 & $0.11 \pm 0.10$ & 105 & $0.11 \pm 0.06$ & 109 & $0.09 \pm 0.05$ & & - \\
\hline Oat & 49 & $0.01^{* *}$ & 102 & $0.24 \pm 0.14$ & 101 & $0.12 \pm 0.09$ & 101 & $0.10 \pm 0.06$ & 100 & $0.09 \pm 0.07$ & & - \\
\hline
\end{tabular}

No. $=$ number of samples

* mean for 1972-1976 (Koivistoinen 1980).

** Ministry of Agriculture and Forestry, 1994.

Each pooled sample of spring and winter wheat and rye represents $0.1-5$ million $\mathrm{kg}$ of grain. Barley and oats samples are non-pooled samples from single farms. 
Ekholm, P. et al.: Selenium concentration of Finnish foods

Table 3. Selenium concentration of Finnish basic foodstuffs (mgkg-1 dry matter) in 1984, 1990, and 1992-1994.

\begin{tabular}{|c|c|c|c|c|c|c|c|c|c|c|}
\hline Sample & No. & $\begin{array}{l}1984 \\
\text { Mean } \pm \text { SD }\end{array}$ & No. & $\begin{array}{l}1990 \\
\text { Mean } \pm \text { SD }\end{array}$ & $\begin{array}{l}\text { No. } \\
\text { No. }\end{array}$ & $\begin{array}{l}1992 \\
\text { Mean } \pm \text { SD }\end{array}$ & $\begin{array}{l}\text { No. } \\
\text { No. }\end{array}$ & $\begin{array}{l}1993 \\
\text { Mean } \pm \text { SD }\end{array}$ & $\begin{array}{l}\text { No. } \\
\text { No. }\end{array}$ & $\begin{array}{l}1994 \\
\text { Mean } \pm \text { SD }\end{array}$ \\
\hline $\begin{array}{l}\text { Wheat flour, } \\
\text { medium coarce }\end{array}$ & 33 & $0.06 \pm 0.03$ & 20 & $0.23 \pm 0.02$ & 19 & $0.14 \pm 0.04$ & 20 & $0.12 \pm 0.02$ & 20 & $0.11 \pm 0.03$ \\
\hline Rye flour, whole meal & 133 & $0.09 \pm 0.05$ & 24 & $0.05 \pm 0.01$ & 20 & $0.07 \pm 0.05$ & 20 & $0.06 \pm 0.03$ & 20 & $0.04 \pm 0.02$ \\
\hline Wheat bread, white & 24 & $0.05 \pm 0.04$ & 16 & $0.23 \pm 0.02$ & 16 & $0.16 \pm 0.03$ & 16 & $0.13 \pm 0.03$ & 16 & $0.10 \pm 0.03$ \\
\hline Rye bread, whole & 24 & $0.07 \pm 0.05$ & 15 & $0.06 \pm 0.02$ & 16 & $0.06 \pm 0.03$ & 16 & $0.07 \pm 0.03$ & 16 & $0.05 \pm 0.01$ \\
\hline Beef steak & 24 & $0.17 \pm 0.06$ & 16 & $0.64 \pm 0.08$ & 16 & $0.49 \pm 0.05$ & 16 & $0.46 \pm 0.05$ & 16 & $0.42 \pm 0.05$ \\
\hline Pork fillet & 24 & $0.35 \pm 0.07$ & 16 & $1.09 \pm 0.09$ & 16 & $0.77 \pm 0.09$ & 16 & $0.71 \pm 0.08$ & 16 & $0.64 \pm 0.06$ \\
\hline Liver, bovine & 24 & $0.65 \pm 0.29$ & 16 & $1.47 \pm 0.38$ & 16 & $1.21 \pm 0.22$ & 16 & $1.15 \pm 0.17$ & 16 & $1.10 \pm 0.19$ \\
\hline $\begin{array}{l}\text { Liver, porcine } \\
\text { Milk, standard }\end{array}$ & 24 & $1.60 \pm 0.29$ & 16 & $2.13 \pm 0.21$ & 16 & $1.90 \pm 0.17$ & 16 & $1.95 \pm 0.16$ & 16 & $1.86 \pm 0.21$ \\
\hline $3.9 \%$ fat & 24 & $0.06 \pm 0.01$ & 16 & 0.21 & 16 & 0.15 & 16 & 0.14 & 16 & $0.13 \pm 0.01$ \\
\hline Cheese, edam & 24 & $0.09 \pm 0.02$ & 16 & $0.42 \pm 0.04$ & 16 & $0.29 \pm 0.02$ & 16 & $0.27 \pm 0.02$ & 16 & $0.25 \pm 0.02$ \\
\hline Egg & 24 & $0.69 \pm 0.15$ & 16 & $1.26 \pm 0.13$ & 16 & $0.99 \pm 0.18$ & 16 & $0.85 \pm 0.08$ & 16 & $0.89 \pm 0.11$ \\
\hline
\end{tabular}

No. $=$ number of samples

with the change in fertilizer composition, as was indeed intended by the switch to one-level Se supplementation. The same reduction in varia- tion was evident in the composition of grassy feeds (Ministry of Agriculture and Forestry 1994).
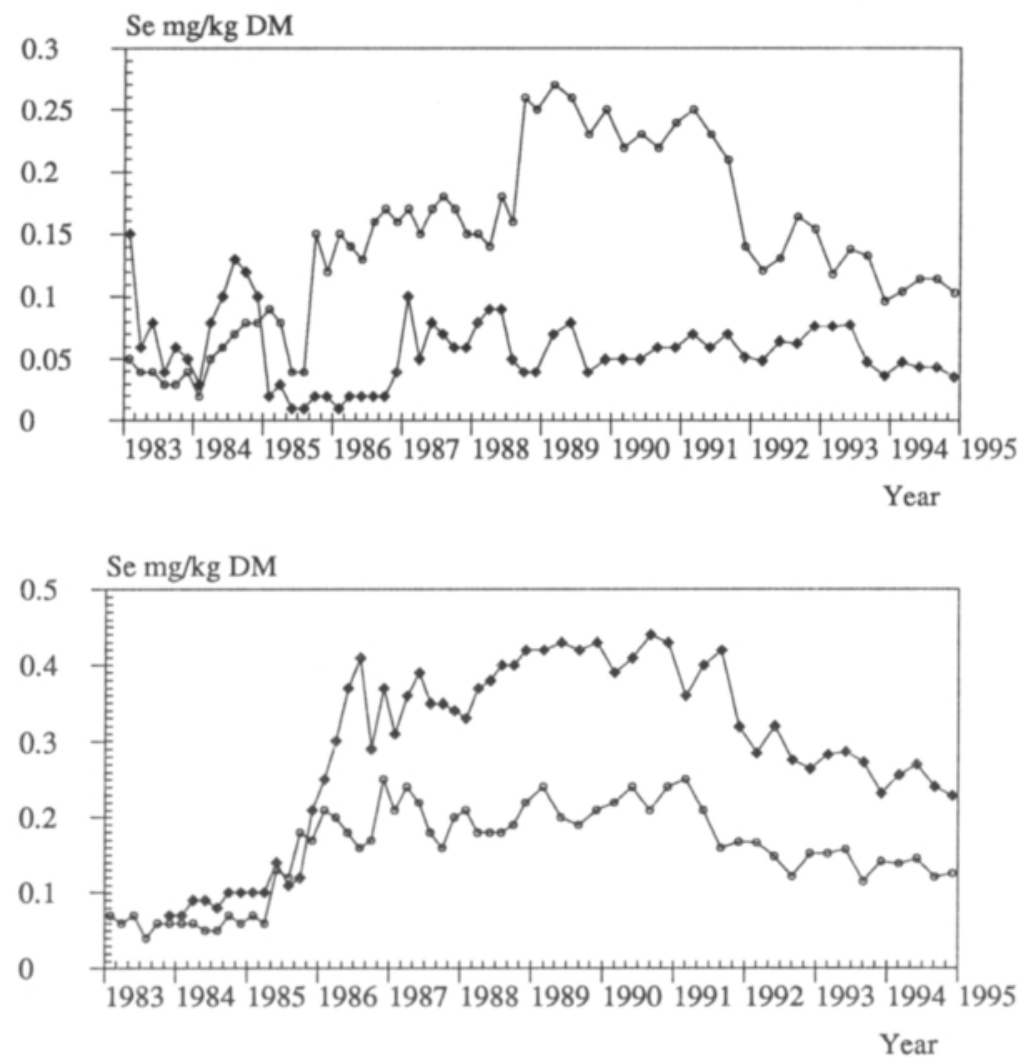

Fig. 1. Trends in selenium concentrations of wheat flour $(\Theta-\Theta)$ and rye flour $(\bullet \bullet)$. Selenium fertilization was started in summer 1985 , and the level of supplementation adjusted in summer 1991.
Fig. 2. Trends in selenium concentrations of milk $(\ominus-\ominus)$ and cheese 
Vol. 4: 377-384.

The overall effect of Se supplementation has been noticeable slight on winter cereals (winter wheat and rye), Se concentrations never exceeding $0.1 \mathrm{mg} \mathrm{kg}^{-1}$. This difference from spring cereals is mainly due to the difference in fertilization practice. However, starting in 1991, the Se concentrations of winter cereals have also decreased (Table 2).

Se concentrations have declined less in other foods than in spring cereals, due to the fact that the lower Se level fertilizers (Se $6 \mathrm{mg} \mathrm{kg}^{-1}$ ) were mainly used in grassy feed production.

The Se concentrations of milk, cheese and eggs have decreased by $30-40 \%$ since 1990 . The Se level of milk is still two to three times higher than that prevailing before Se supplementation practice (Table 3). The use of selenite-supplemented commercial feeds was already common in egg production in the 1970s and 1980s. Consequently, in 1994 the Se concentration of eggs was only slightly higher than that in 1984 , before Se was added to fertilizers.

The change to one-level Se fertilization has decreased the beef Se concentration by more than $30 \%$, and pork Se by $40 \%$ (Table 3, Figs. 3 and 4 ). The changes have been less marked in bovine and porcine livers than in the corresponding musculous tissues. The Se concentrations of skeletal muscles and other soft tissues are known to be linearly dependent on the Se concentration of the diet, and to reach a plateau level with the rising Se (Mahan and Moxon 1978, Sankari 1985, Eschewaria et al. 1988). The Se concentration of liver reaches its plateau at a lower dietary level (Se $0.25 \mathrm{mg} \mathrm{kg}^{-1}$ fodder) than musculous tissue (over $0.40 \mathrm{mg} \mathrm{kg}^{-1}$ fodder) (Ekholm et al. 1991b). The present Se concentration of feeds is still high enough to keep the Se concentration of liver near its saturation level.

The decrease in the concenration of $\mathrm{Se}$ in
Fig. 3. Trends in selenium concentrations of pork fillet $(\Theta-\ominus)$ and beef steak $(\bullet \bullet)$.

Fig. 4. Trends in selenium concentrations of bovine liver $(\Theta-\Theta)$ and porcine liver (
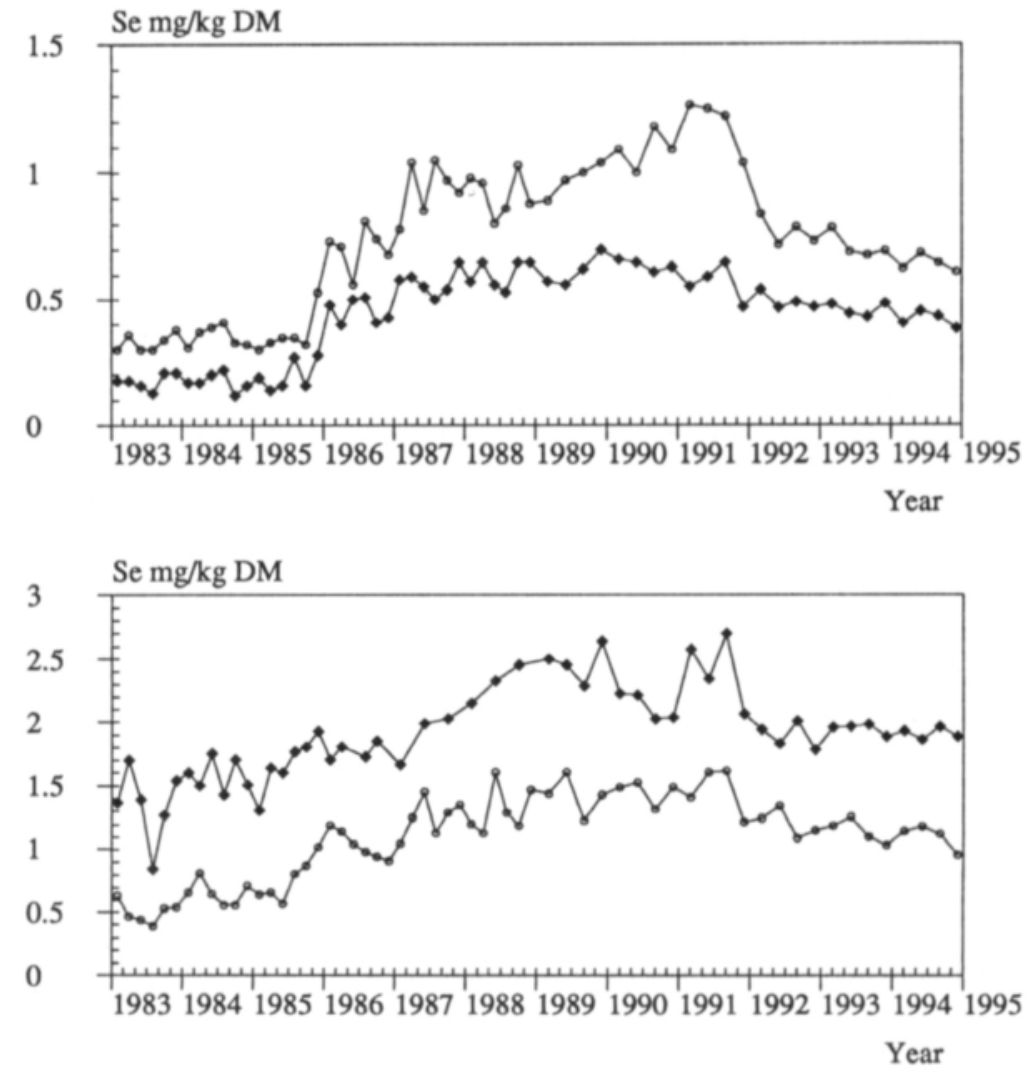
Ekholm, P. et al.: Selenium concentration of Finnish foods

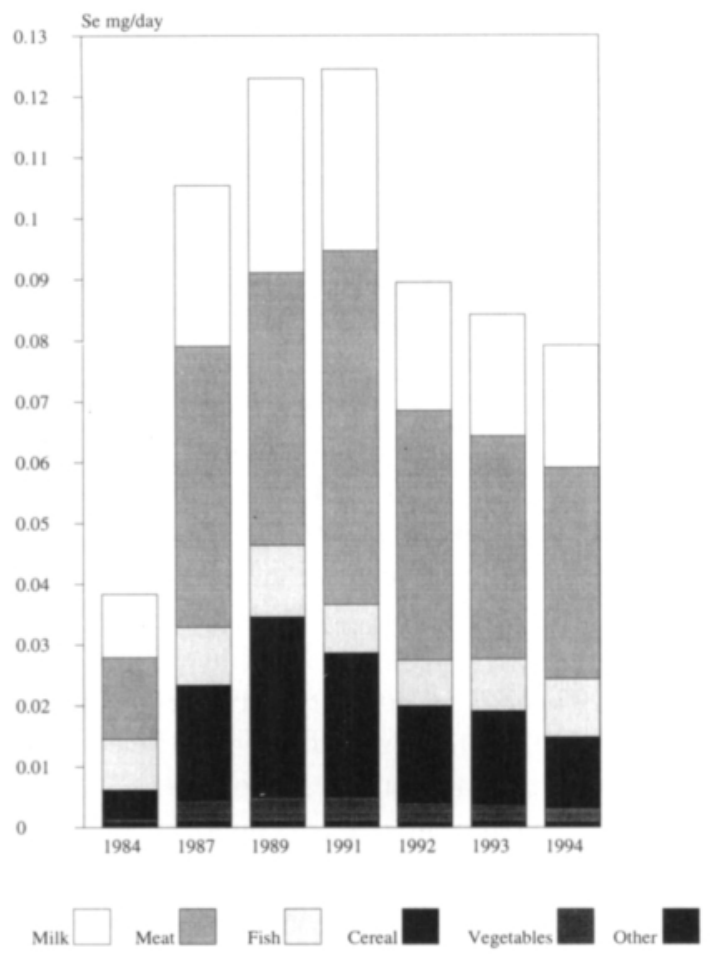

Fig. 5. Average daily selenium intake in Finland at energy level of $10 \mathrm{MJ}$.

fertilizers has lowered the average daily human intake of Se. In 1994, the intake was $0.08 \mathrm{mg} \mathrm{d}^{-1}$ as calculated from Finnish food consumption statistics at an energy level of $10 \mathrm{MJ}(2400 \mathrm{kcal})$ (Agricultural Economics Research Institute 1993) (Fig. 5). This is well within the recommendations of the United States $(0.055 \mathrm{mg}$ for women and $0.070 \mathrm{mg}$ for men) (National Academy of Sciences 1989) and Scandinavia (0.03$0.06 \mathrm{mg} \mathrm{day}^{-1}$ (Nordic Council of Ministers 1989). Average Se intake is still higher in Finland than in most other European countries, and is at almost the same level as in some parts of the United States and Canada (Levander and Morris 1984, Dokkum et al. 1989, Oster and Prellwitz 1989, Bratakos and Ioannou 1991, Pennington and Young 1991).

About $40 \%$ of the Se intake comes from meat, $24 \%$ from dairy products and eggs, and $11 \%$ from fish. Animal protein is thus the main source of

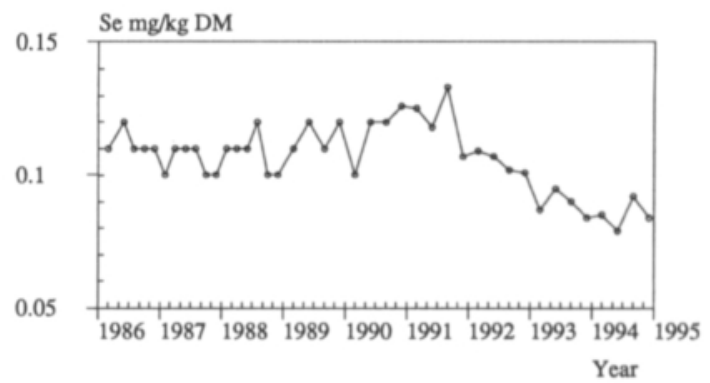

Fig. 6. Trend in selenium concentration of human milk.

dietary Se. Cereal products account for $19 \%$ of total intake. Overall Se intake may still be decreasing slightly (Fig. 5).

In Finland, imports of Se rich North American wheat had a major impact on average daily Se intake in the 1970s and early 1980s (Varo and Koivistoinen 1981). During the use of Se-supplemented fertilizers grain imports have had only a moderate effect on Se intake. In 1988-1989 of imported wheat consisted relatively high proportion, about $25 \%$ of commercial milling. However, the Se intake was slightly lower in 1989 than in 1991, when all milled wheat was again domestic.

The Se concentration of mothers' milk correlates well with the estimated Se intake (Fig. 6). During the period of Se supplementation, the Se concentration of breast milk increased from $0.05 \mathrm{mg} \mathrm{kg}^{-1}$ dry matter in 1977 (Koivistoinen 1980 ) to about $0.11 \mathrm{mg} \mathrm{kg}^{-1}$ dry matter in 1990. In comparison with cow's milk the Se concentration of human milk is low due to its lower protein concentration. The effect of decreased dietary Se intake on the Se concentration of breast milk was evident in 1992. No futher decrease was noted in 1994, indicating that $\mathrm{Se}$ intake is reaching a new plateau.

Changes in the serum Se of both the urban and rural population have been consistent with changes in the estimated average Se intake (Ministry of Agriculture and Forestry 1994). This confirms the validity of the method used in to calculate average intake.

The present level of Se in foods guarantees a safe and adequate intake with all kinds of diets. 
Vol. 4: 377-384.

Excessive food-based intakes are not possible, not even in exceptional dietary compositions. In Finland the Se supplementation of fertilizers has proved to be an effective, safe and controlled way of bringing the Se intake of the whole population up to a nutritionally adequate level.

\section{References}

Agricultural Economics Research Institute 1993. Balance sheet for food commodities. Helsinki. 8 p.

Aspila, P. 1991. Metabolism of selenite, selenomethionine and feed-incorporated selenium in lactating goats and dairy cows. Journal of Agricultural Science in Finland 63: 1-74.

Bratakos, M. S. \& Ioannou, P. V. 1991. Selenium in human milk and dietary selenium intake by Greeks. The Science of the Total Environment 105: 101-107.

Conrad, H. R. \& Moxon, A. L. 1979. Transfer of dietary selenium to milk. Journal of Dairy Science 62: 404-411. Dokkum, W. van, Vos, R. H. de, Muys, T. H. \& Wesstra, J. A. 1989. Minerals and trace elements in total diets in the Netherlands. British Journal of Nutrition 61: 7-15.

Ekholm, P., Varo, P., Aspila, P., Koivistoinen, P. \& Syrjälä-Qvist, L. 1991b. Transport of feed selenium to different tissues of bulls. British Journal of Nutrition 66: 49-55. -, Ylinen, M., Eurola, M., Koivistoinen, P. \& Varo P. 1991a. Effects of general soil fertilization with sodium selenate in Finland on the selenium content of milk, cheese and eggs. Milchwissenschaft 46: 547-550.

-, Ylinen, M., Koivistoinen, P. \& Varo P. 1990. Effects of general soil fertilization with sodium selenate in Finland on the selenium content of meat and fish. Journal of Agricultural and Food Chemistry 38: 695-698.

Echevarria, M. G., Henry, P. R., Ammerman, C. B. \& Rao, P. V. 1988. Effects of time and dietary selenium concentration as sodium selenite on tissue selenium uptake by sheep. Journal of Animal Science 66:2299-2305. Eurola, M., Ekholm, P., Ylinen, M., Koivistoinen, P. \& Varo P. 1989. Effects of selenium fertilization on the Se content of selected Finnsh fruits and vegetables. Acta Agriculturae Scandinavica 39: 345-350.

-, Ekholm, P., Ylinen, M., Koivistoinen, P. \& Varo, P. 1990. Effects of selenium fertilization on the selenium content of cereal grains, flour and bread produced in Finland. Cereal Chemistry 67: 334-337.

-, Ekholm, P., Ylinen, M., Koivistoinen, P. \& Varo, P. 1991. Selenium in Finnish foods after beginning the use of selenate supplemented fertilizers. Journal of the Science of Food and Agriculture 56: 57-70.

Jacobsen, S. O., Oksanen, H. E. \& Hansson, E. 1965. Excretion of selenium in the milk of sheep. Acta Veteri- naria Scandinavica 6: 299-312.

Koivistoinen, P. 1980. Mineral element compositions of Finnish foods. I-XII. Acta Agriculturae Scandinavica Supplement 22. $171 \mathrm{p}$.

Kumpulainen, J., Raittila, A.-M., Lehto, J. \& Koivistoinen, P. 1983. Electrothermal atomic absorption spectrometric determination of selenium in foods and diets. Journal of the Association of Official Analytical Chemists 66: $1129-1135$.

Levander, O. A. \& Morris, V. C. 1984. Dietary selenium levels needed to maintain balance in North American adults consuming self-selected diets. The American Journal Clinical Nutrition 39: 809-815.

Mahan, D. C. \& Moxon, A. L. 1978. Effects of adding inorganic and organic selenium sources to the diets of young swine. Journal of Animal Science 47: 456-466.

Ministry of Agriculture and Forestry 1990. Annual report IV. Working Group Report No 12. Helsinki. 29 p. (in Finnish).

- 1994 Annual report. Working Group Report No 2. Helsinki. 36 p. (in Finnish)

National Academy of Science 1989. Recommended Dietary Allowances. 10th ed. National Research Counsil, Washington. $284 \mathrm{p}$.

Nordic Council of Ministers 1989. Nordic dietary recommendations. Report 2. Copenhagen. 16 p.

Oster, O. \& Prellwitz, W. 1989. The daily selenium intake of West German Adults. Biological Trace Element Research 20: 1-14.

Pennington, J. A. T. \& Young, B. E. 1991. Total diet study nutritional elements, 1982-1989. Journal of the American Dietetic Associaton 91: 179-183.

Sankari, S. 1985. Plasma glutathione peroxsidase and tissue selenium response to selenium supplementation in swine. Acta Veterinaria Scandinavica 81: 1-127.

Varo, P. \& Koivistoinen, P. 1981. Annual variations in the average selenium intake in Finland: Cereal products and milk as sources of selenium in 1979/80. International Journal of Vitamin and Nutrition Research 51: 79-84. -, Alfthan, G., Ekholm, P., Aro, A. \& Koivistoinen, P. 1988. Selenium intake and serum selenium in Finland: Effects of soil fertilization with selenium. The American Journal of Clinical Nutrition 48: 324-329. 
Ekholm, P. et al.: Selenium concentration of Finnish foods

\title{
SELOSTUS
}

\section{Seleenilannoituksen muutoksen vaikutus suomalaisten elintarvikkeiden seleenipitoisuuteen}

\author{
Päivi Ekholm, Maija Ylinen, Pekka Koivistoinen ja Pertti Varo \\ Helsingin yliopisto
}

Seleenilannoituskäytäntöä muutettiin siten, että vuodesta 1991 alkaen kaikissa moniravinnelannoitteissa on ollut yhtä paljon natriumselenaattia (Se $6 \mathrm{mg} \mathrm{kg}^{-1}$ lannoitetta) aikaisemmin käytetyn kahden seleenilisäyksen sijasta. Toimenpiteellä haluttiin ennen kaikkea estää eläinten rehuissa esiintyneitä suuria seleenipitoisuuksia, joita oli havaittu eräissä yksittäistapauksissa.

Kaikkien seurattujen elintarvikkeiden seleenipitoisuudet olivat laskeneet lannoituskäytännön muutoksen vuoksi. Kevätviljojen seleenipitoisuudet olivat laskeneet eniten (yli $60 \%$ ), koska vuosina 1985-
1990 lannoitteissa käytetty seleenitaso $16 \mathrm{mg} \mathrm{kg}^{-1}$ oli tarkoitettu viljanviljelyyn. Muiden elintarvikkeiden seleenipitoisuudet olivat laskeneet vähemmän kuin kevätviljojen. Lihan seleenipitoisuus oli laskenut $\mathrm{n}$. $30 \%$, maidon ja juuston yli $30 \%$. Muutos on ollut pienin naudan ja sian maksan kohdalla (10-20\%).

Elintarvikkeiden seleenipitoisuuksien lasku oli vaikuttanut myös suomalaisten keskimääräiseen päivittäiseen seleenin saantiin Suomessa. Vuonna 1994 seleenin saanti oli $10 \mathrm{MJ}: \mathrm{n}$ energiatasolla $0,08 \mathrm{mg} \mathrm{d}^{-1}$. Seleenin saantimme vastasi hyvin kansainvälisiä suosituksia ja oli riittävä ja turvallinen. 